\title{
Review
}

\section{The role of neuropeptides in caterpillar nutritional ecology}

\author{
Jacqueline C. Bede ${ }^{a, *}$, Jeremy N. McNeil ${ }^{b}$, Stephen S. Tobe ${ }^{c}$ \\ ${ }^{a}$ Department of Plant Science, McGill University, Ste-Anne-de-Bellevue, Que., Canada H9X 3V9 \\ ${ }^{b}$ Department of Biology, University of Western Ontario, London, Ont., Canada N6A 5B7 \\ ${ }^{\mathrm{c}}$ Department of Cell and Systems Biology, University of Toronto, Toronto, Ont., Canada M5S 3G5
}

\section{A R T I C L E I N F O}

Article history:

Received 27 June 2006

Received in revised form

10 August 2006

Accepted 10 August 2006

Published on line 11 December 2006

Keywords:

Neuropeptides

Nutritional ecology

Nutrient requirements

\begin{abstract}
A B S T R A C T
Plant diet strongly impacts the fitness of insect herbivores. Immediately, we think of plant defensive compounds that may act as feeding deterrents or toxins. We are, probably, less aware that plants also influence insect growth and fecundity through their nutritional quality. However, most herbivores respond to their environment and select the diet which optimizes their growth and development. This regulation of nutritional balance may occur on many levels: through selecting and ingesting appropriate plant tissue and nutrient digestion, absorption and utilization. Here, we review evidence of how nutritional requirements, particularly leaf protein to digestible carbohydrate ratios, affect caterpillar herbivores. We propose a model where midgut endocrine cells assess and integrate hemolymph nutritional status and gut content and release peptides which influence digestive processes. Understanding the effects of diet on the insect herbivore is essential for the rational design and implementation of sustainable pest management practices.
\end{abstract}

(c) 2006 Elsevier Inc. All rights reserved.

\section{Contents}

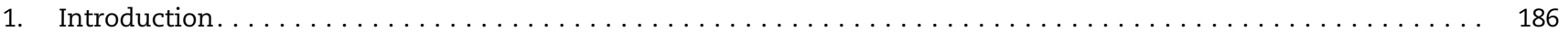

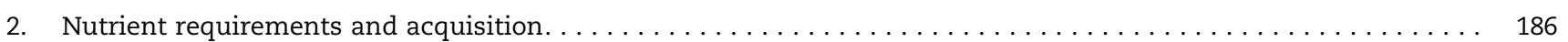

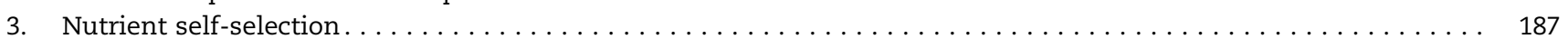

4. Endocrine regulation of digestive processes and nutrient acquisition $\ldots \ldots \ldots \ldots \ldots$

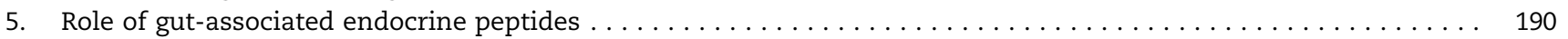

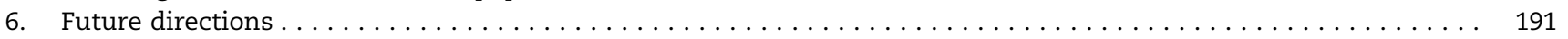

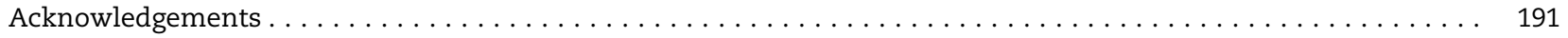

References . . . . . . . . . . . . . . . . . . . . . . . . . . . . . . . . . . . 191

* Corresponding author at: Department of Plant Science, McGill University, Ste-Anne-de-Bellevue, Que., Canada H9X 3V9.

Tel.: +1 5143987860 .

E-mail address: jacqueline.bede@mcgill.ca (J.C. Bede).

Abbreviations: AKH, adipokinetic hormone; CC, corpora cardiaca; CCAP, crustacean cardioactive peptide; CNS, central nervous system; $\mathrm{EC}$, endocrine cells; $\mathrm{P}: \mathrm{C}$, ratio of protein to digestible carbohydrate 0196-9781/\$ - see front matter (C) 2006 Elsevier Inc. All rights reserved. doi:10.1016/j.peptides.2006.08.030 


\section{Introduction}

Interactions between herbivorous insects and plants have been a major research focus for many years $[28,35,60]$, not only to gain insights into the fundamental ecological and evolutionary aspects of such interspecific interactions, but also in the search for effective and ecologically acceptable alternatives to synthetic insecticides for the management of pest species.

Herbivorous insects must find sufficient nutrient resources of acceptable quality to permit normal growth, development and reproduction $[8,102,143]$. However, difficulties in acquiring suitable food is complicated by plant defenses that act to reduce the level and/or impact of herbivory. These defense mechanisms may be of a structural (e.g. leaf toughness, waxes or trichomes $[79,90])$ and/or chemical (e.g. feeding deterrents, toxins [145]) nature. In addition, chemical defenses may be constitutive or induced in response to herbivory $[56,60]$ or even the deposition of eggs [43]. Furthermore, indole, terpenoid or c6-derived volatiles associated with induced plant defenses can be used as host location cues by parasitoids and predators and provide additional indirect defenses against herbivores $[31,43,59]$.

Herbivores have, therefore, evolved mechanisms that not only allow them to find and exploit plants that meet their nutritional needs, but also permit them to avoid, circumvent, or minimize potential effects of direct and indirect plant defenses. In the extreme, the failure to do so would result in death. However, there are also more subtle effects attributable to plant defenses and/or poor nutritional quality of host plants. Herbivores feeding on low quality, well-defended plants may develop more slowly than those on high quality ones, thereby increasing potential exposure time to natural enemies $[7,101,128]$. In addition, these conditions may result in adults that have lower reproductive success $[8,26,80]$, or influence processes, such as diapause or migration $[50,71]$. The challenges facing herbivores is further complicated by the fact that both intra- and inter-plant nutritional quality will vary temporally and spatially, depending upon abiotic (e.g. temperature, light, relative humidity and soil quality) and biotic (e.g. intra- and inter-specific competition) factors $[82,112,104,138]$. Similarly, levels of defenses vary temporally and spatially both within and between plants of the same species $[48,106,139]$. Consequently, understanding how insect herbivores cope with such variation in both host plant nutrient value and defenses has generated considerable interest $[12,124]$.

\section{Nutrient requirements and acquisition}

Insect herbivores rely on host plants for many nutritional components, including water, phytosterols, vitamins and lipids $[111,123]$. In particular, the acquisition of an appropriate amounts and ratio of protein to digestible carbohydrates $(\mathrm{P}: \mathrm{C})$ from the diet is essential for efficient growth and development [119]. This key parameter has been the subject of many feeding studies and will serve as the framework for the ideas presented in this review on the possible roles of neuropeptides in the regulation of feeding in larval Lepidoptera. The optimal nutritional P:C ratio for a herbivore depends on inter- and intra-specific factors and their interactions. For example, dietary requirements may depend on whether the herbivore is a hemimetabolous or holometabolous insect. In the former, similar food sources are exploited by all life stages, whereas in holometabolous insects, immature stages and adults have different diets and, often, a considerable portion of adult requirements must be obtained during larval development $[129,130]$. Similarly, nutritional requirements may vary depending on whether the herbivore is a generalist or a specialist (Table 1). For example, in choice feeding experiments, caterpillars of two generalist species, the Egyptian cotton leafworm, Spodoptera littoralis, and the beet armyworm, S. exigua, selected a diet containing higher protein content than the grass specialist, S. exempta $([68,71]$ Bede, unpublished).

Even within a given species, requirements may change dramatically from one developmental stage to another. Early instar caterpillars require nutrients mainly for growth, whereas, the later instars must also acquire resources needed by the pupal and adult stages. Nutrient selection of late instar male and female caterpillars may also reflect their distinct physiological requirements $[129,130]$. Intraspecific differences may also be related to other ecological parameters, such as changes in population density, as seen with the solitary and gregarious phases of the desert locust, Schistocerca gregaria [122] or the African armyworm, S. exempta [71]. Similarly, the dietary requirements of larvae may change as a consequence of parasitism or pathogen infections [72,135].

The first step in acquiring a suitable diet is the selection of host plants by gravid females, a process modulated by visual, mechanical and chemical cues [18]. The selection of high quality host plants is of considerable importance because the larval stages, particularly neonates, generally have limited mobility. However, it is these immature stages that must, through diet

Table 1 - Caterpillar dietary self-selected dietary ratio of protein to digestible carbohydrate (P:C)

\begin{tabular}{|c|c|c|c|c|c|}
\hline Insect species & Diet breadth & $\begin{array}{l}\text { Parasitized } \\
\text { state }\end{array}$ & Stage & $\begin{array}{l}\text { Intake target } \\
\text { (ratio } \mathrm{P}: \mathrm{C})\end{array}$ & Reference \\
\hline Helicoverpa zea & Generalist & & 5 th instar & $79: 21$ & [142] \\
\hline Spodoptera littoralis & Generalist & & 6 th instar & 23.9:18.1 & [68] \\
\hline S. exigua & Generalist & & 2nd to pupation & $22: 20$ & Bede, unpublished \\
\hline Heliothis virescens & Generalist & & 5th instar & $25.8: 16.2$ & [73] \\
\hline S. exempta & Specialist_grasses & & 6th instar & $18.5: 23.5$ & [69] \\
\hline H. subflexa & $\begin{array}{l}\text { Specialist-Physalis genera } \\
\text { in the Solanaceae }\end{array}$ & & 5 th instar & 19.9:22.1 & [73] \\
\hline Malacosoma disstria & Specialist & & 4th instar & Random feeding & [27] \\
\hline \multirow[t]{2}{*}{ Manduca sexta } & Specialist-Solanaceae & & 5th instar & $1: 1$ & [137] \\
\hline & & Parasitized & 5 th instar & Random feeding & [137] \\
\hline
\end{tabular}


selection, ensure they have a nutritionally balanced intake. Switching between feeding sites, either on the same plant or moving to another plant, is an important strategy to maintain an optimal P:C ratio, avoid plant defenses, or both $[15,41,89,117]$.

All herbivorous insects must find solutions to circumvent the relative variation in the abundance of plant carbohydrates and proteins, but as polyphagous insects generally face greater dietary heterogeneity compared to mono- and oligophagous ones. Therefore, they often possess additional metabolic strategies to deal with dietary nutrient imbalances $[68,69,103,122]$. Phytophagous caterpillars tend to select and show optimal performance (survivorship, growth and development and fecundity) on balanced or slightly protein-biased diets (Table 1) $([27,68,70,130,131]$ Bede, unpublished). However, while plants often contain sufficient or excess carbohydrates (i.e. sucrose), proteins may be limiting in quantity and/or quality $[32,57,82,111,138]$. Therefore, to obtain sufficient protein resources, larvae must limit the detrimental effects of excess carbohydrate consumption $[68,70,131,142]$ One post-ingestive mechanism to cope with excess glucose is elevated respiration, which has been demonstrated in locust, and assumed to occur in caterpillars $[131,149]$. Another strategy may be to metabolize excess carbohydrates prior to ingestion through enzymes secreted in the saliva. Glucose oxidase, which catalyzes the oxidation of glucose to gluconate and hydrogen peroxide, has been detected in the salivary secretions and/or glands of generalist caterpillars of the beet armyworm, S. exigua, the cotton bollworm, Helicoverpa armigera, Heliothis assulta and the corn earworm, H. zea $[29,84,156]$. Hydrogen peroxide produced by this reaction may interfere with plant defensive pathways induced in response to caterpillar herbivory [92,93]. However, it is also possible that altering the levels of salivary glucose oxidase activity may be a strategy used by caterpillars to cope with different plant P:C levels. For example, when beet armyworm larvae are transferred from the plant Medicago truncatula to a carbohydrate-rich artificial diet, glucose oxidase activity increases significantly [84]; whether this response is an effective means of dealing with excess dietary glucose remains to be determined.

Insect herbivores have post-ingestion mechanisms to deal with diets that contain excess protein and are carbohydratedeficient. Strategies to eliminate excess dietary nitrogen are species-specific $[130,131]$. Female Estigmene acrea larvae excrete a constant percentage of dietary protein without assimilation. Therefore, as protein intake increases, more nitrogen is egested. Other insect herbivores use the amino acids from excess protein to derive needed carbon skeletons through deamination and gluconeogenesis, with the excess nitrogen being excreted as uric acid [130,133,136].

\section{Nutrient self-selection}

One aspect of the question "how do phytophagous insects adapt their feeding behavior to meet their changing nutritional needs and cope with variation in plant quality" relates to the integration of insect metabolic state, dietary intake and the rapid changes observed in the digestive processes and feeding behavior. Many studies have focused on the role of chemosensory information in mediating feeding decisions
$[14,20]$. These include changes in chemoreceptor sensitivity to amino acids and/or sucrose in herbivores reared on suboptimal diets $[2,16]$ and how these may result in behavioral changes $[16,120,121]$. Clearly, feedback loops between the levels of sugars and amino acids in the hemolymph and the peripheral chemosensory system play an important role in modulating these activities [119]. In addition, behavioral learning adds an additional layer of complexity to this whole process $[13,116,118]$. However, changes at the peripheral chemosensory system may not provide all of the necessary information [16]. Evidence, such as the observation that maxillectomized caterpillars did not recognize appropriate host plants yet still select the optimal P:C dietary ratio [4], indicates that other physiological mechanisms may be working in conjunction with information from peripheral chemoreceptors to regulate feeding behavior.

An examination of recent literature on carbohydrate metabolism in feeding and starved insects could provide insight into the metabolic and behavioral processes mediating food choice in caterpillars and the role of neuropeptides in regulating these physiological changes. We recognize that targeting carbohydrate and protein nutritional uptake is regulated by different mechanisms, but at some level must be precisely integrated. We have chosen to concentrate on the more abundant body of carbohydrate literature for the development of the ideas put forward in this paper. In actively feeding individuals, sucrose obtained from food is hydrolyzed to glucose and fructose by the midgut enzyme invertase, resulting in elevated glucose levels in the hemolymph. Once taken up by the fat body (Fig. 1), glucose can undergo glycolysis and provide energy, or be used for the synthesis of either trehalose, the principal hemolymph carbohydrate in lepidopteran larvae [132], or glycogen, for storage [19]. These two pathways compete

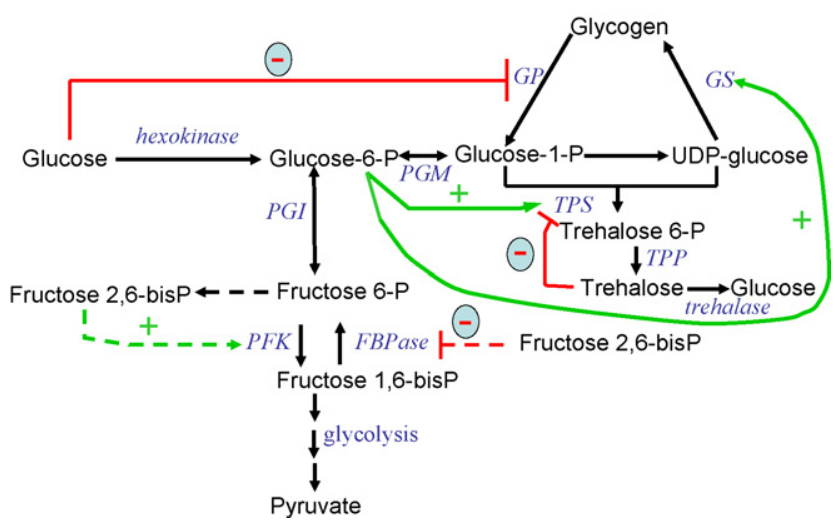

Fig. 1 - Carbohydrate metabolism in caterpillar fat body. Positive feedback of metabolic enzymes is indicated by a "+" sign, whereas negative feedback of pathways is designated by a "-" sign. Dashed lines represent hypothetical pathways based on vertebrate information. The multi-enzymatically catalyzed steps of glycolysis are represented by multiple arrows. Enzyme are italicized and abbreviated as: FBPase: fructose 1,6-bisphosphatase; GP: glycogen phosphorylase; GS: glycogen synthase; PFK: 6phosphofructo-1-kinase; PGI: phosphoglucoisomerase; PGM: phosphoglucomutase; TPP: trehalose 6-phosphate phosphatase; TPS: trehalose 6-phosphate synthase. 
for the available glucose, as the phosphate form of glucose, glucose-6-phosphate, allosterically activates both trehalose 6phosphate synthase and glycogen synthase. However, fat body trehalose synthase has a higher affinity for glucose-6-phosphate than glycogen synthase [91]; accordingly, at low glucose levels, trehalose is preferentially synthesized. As levels of trehalose increase, there is feedback inhibition of trehalose synthase, resulting in elevated levels of glucose-6-phosphate [91]. This, in turn, leads to the activation of glycogen synthase and the inhibition of glycogen phosphorylase, shifting metabolism toward glycogen synthesis [5].

In caterpillars, hemolymph levels of glucose and trehalose are not regulated by homeostatic mechanisms and as they may fluctuate quickly, they reflect the insect's nutritional intake and metabolic state [132]. For example, during shortterm food deprivation $(<3 \mathrm{~h})$, trehalose levels remain relatively stable in larvae of the tobacco hornworm, Manduca sexta, and the silk moth, Bombyx mori whereas glucose levels drop drastically $[40,81,86,110,113,115]$. Such a decrease in glucose relieves the inhibition on glycogen phosphorylase, resulting in increased activity of this enzyme (Fig. 2A) [40,86,110,113,115]. The resulting degradation of glycogen in the fat body results in an increase in glucose-6-phosphate, which will then be directed to trehalose biosynthesis. Under extreme starvation, when fat body glycogen stores are depleted, the activity of glycogen phosphorylase decreases (Fig. 2A) [40,113,115]; this is

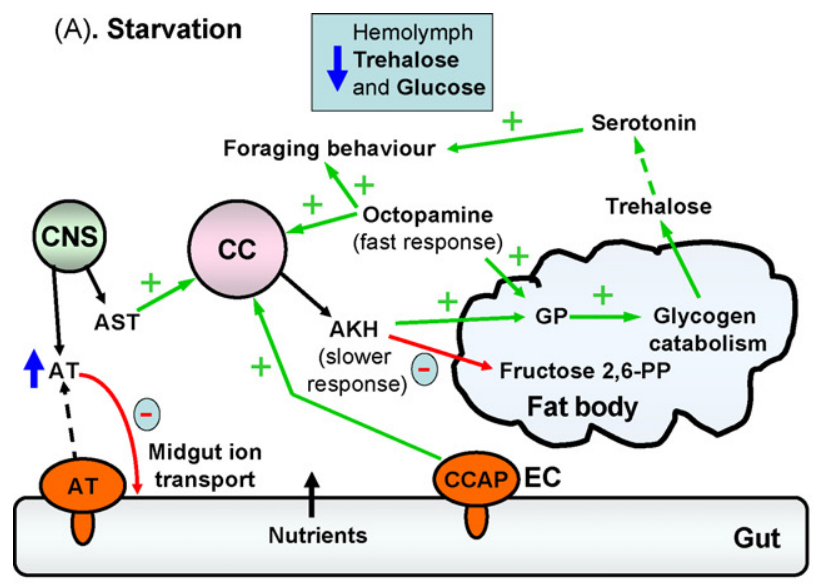

\section{(B). Switch to carbohydrate-rich diet}

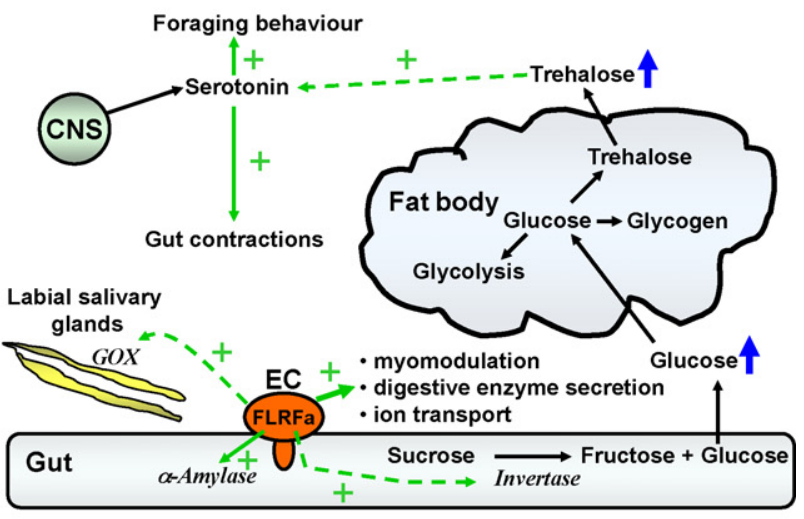

(D). Switch to balanced diet

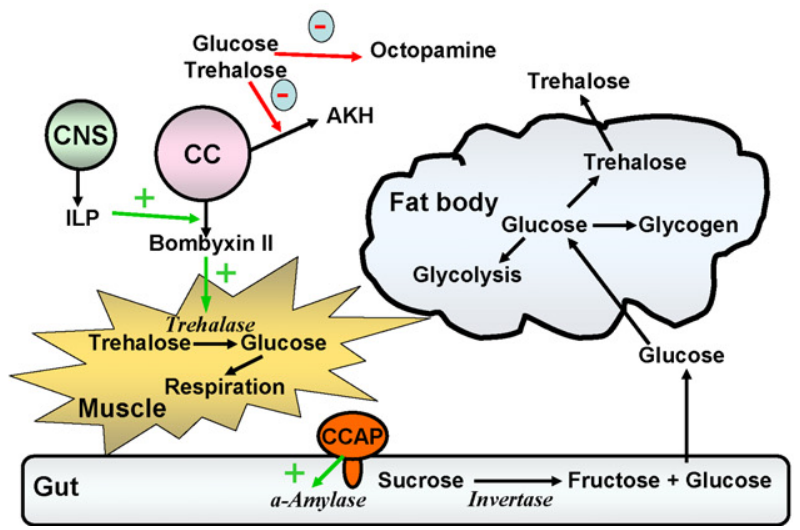

Fig. 2 - Proposed interactions contributing to digestive processes in lepidopteran larvae. These figures represent putative endocrine and metabolite interactions that may occur when caterpillars are starved (A) or switched from the starved state to a carbohydrate-rich, protein-poor diet (B) or a protein-rich, carbohydrate-poor diet (C) or fed a balanced diet (D). When caterpillars are deprived of nutrients, initially hemolymph glucose levels will fall and trehalose levels remain stable. Under conditions of severe starvation, hemolymph trehalose levels will also decline. Endocrine cells (EC) monitor nutritional content of the ingested food and the hemolymph metabolic state. Midgut EC cells may release peptides which assist in digestive processes by affecting the release and/or activity of digestive enzymes, stimulate muscle contractions or ion transport. At present, it is largely unclear what mediate caterpillar foraging behavior on protein-rich diets (C). Positive interactions are indicated by a "+" sign, whereas negative interactions are shown by a "-" sign. Endocrine peptides may stimulate, inhibit or modulate physiological processes. Known interactions are indicated with solid lines, while proposed interactions are designated by dashed lines. Abbreviations: AKH: adipokinetic hormone; AST: allatostatin; AT: allatotropin; CCAP: crustacean cardioactive peptide; CC: corpora cardiaca; CNS: central nervous system; EC: endocrine cell; FLRFa: FLRFamide related peptide; Fructose 2,6-PP: fructose 2,6-diphosphate; GOX: glucose oxidase; GP: glycogen phosphorylase; ILP: insulin-like peptide. Enzymes are italicized. 
followed by a decline in hemolymph trehalose $[110,132]$. Thus, when a caterpillar stops feeding or is subjected to "starvation" conditions as a result of food deprivation, moulting, gut purging and wandering behavior or parasitization [3,114], glycogen stores are metabolized to maintain hemolymph sugar (trehalose, glucose) levels. Conversely, following the resumption of feeding, there is a decrease in fat body glycogen phosphorylase activity $[81,86]$. A similar decline in enzyme activity was observed following an injection of glucose or, to a lesser extent, trehalose into food-deprived larvae of $M$. sexta [115], providing additional evidence that hemolymph glucose levels affects glycogen phosphorylase activity of fat body; this is most likely associated with the allosteric regulation of this enzyme. Enzyme levels vary within minutes following the onset of feeding, leading Siegert and Mordue [115] to propose an endocrine regulation of fat body glycogen metabolism since these changes occur too rapidly for the process to be directly regulated by changes in hemolymph glucose levels.

\section{Endocrine regulation of digestive processes and nutrient acquisition}

There is mounting evidence that the neuroendocrine hormones, adipokinetic hormone (AKH) and octopamine, may act on the fat body to activate glycogen phosphorylase (Fig. 2A). Hemolymph trehalose levels in larvae of $M$. sexta and B. mori declined rapidly following neck-ligation that prevents hormones of the central nervous system (CNS), such as AKH, from affecting the fat body $[86,109,110]$. Conversely, injection of corpora cardiaca extract or AKH into fed, neck-ligated $M$. sexta larvae results in the increased activity of fat body glycogen phosphorylase [86,115,150-152]. These experiments suggest that $\mathrm{AKH}$, released from the corpora cardiaca, activates fat body glycogen phosphorylase and, consequently, glycogen is metabolized to maintain hemolymph trehalose levels $[40,52,114,115,151]$. AKH also mediates lipid mobilization in caterpillars [153] and these lipids, possibly acting as alternate substrates for respiration, may aid in the maintenance of stable hemolymph trehalose levels in starved insects [110].

As noted above, starved $M$. sexta larvae not only show increased fat body glycogen phosphorylase activity but also reduced levels of fructose-2,6-bisphosphate, which exerts fine control over glycolysis or gluconeogenesis through allosteric effects on the enzymes fructose-6-kinase and/or fructose-1,6bisphosphatase (Fig. 1) $[11,19,86]$. AKH may also affect the catabolism of glycogen, leading to the release of trehalose through its effect on fructose-2,6-bisphosphate, as this metabolite declined following incubation of fat body from the Argentine cockroach, Blaptica dubia, with corpora cardiaca extract or AKH [9-11]. A decline in the levels of this regulatory metabolite alters the relative activities of fructose-6-kinase and fructose-1,6-bisphosphatase, resulting in the inhibition of glycolysis and stimulation of gluconeogenesis [19]. Another potential role of $\mathrm{AKH}$ that merits investigation is its possible role in larval foraging, as this peptide has been implicated in the regulation of starvation-induced foraging behavior of Drosophila melanogaster adults [52,67].

Hemolymph levels of the biogenic amine, octopamine, the "invertebrate stress hormone" [105], have been correlated with foraging behavior and feeding activity $[25,87]$. Furthermore, there are reports that this amine affects the activity of fat body glycogen phosphorylase and, consequently, the catabolism of glycogen stores to maintain hemolymph trehalose levels in starved caterpillars $[53,85]$. It is possible that hemolymph octopamine also has an indirect effect on glycogen catabolism in caterpillars, if it potentiates the release of $\mathrm{AKH}$ from the glandular cells in the corpora cardiaca, as reported in locusts (Fig. 2A) [98]. Octopamine may also affect glycolysis, since it increases the activity of trehalase, the enzyme that hydrolyzes trehalose to glucose in the cockroach, Periplaneta americana [54]. In feeding insects, high levels of hemolymph sugars inhibit both octopamine-dependent mobilization of glycogen and $\mathrm{AKH}$ release from the corpora cardiaca [33,99].

The injection of phentolamine, an adrenergic blocking agent, into neck-ligated, starved caterpillars inhibits fat body responses to $\mathrm{AKH}$ and octopamine but did not stop the elevation of fat body glycogen phosphorylase activity [85]. These findings led Meyer-Fernandes et al. [85] to suggest that other endocrine factors, including the insulin-like peptides that have been isolated from the fruit fly, D. melanogaster, and the silkmoth, B. mori (i.e. bombyxin I-V) $[17,58]$ may be involved in modulating hemolymph sugar levels during food deprivation. Feeding triggers the expression and release of a subset of these insulin-like peptides from neurosecretory cells in the CNS of D. melanogaster larvae and adults and B. mori (Fig. 2D) [51,81], as does the injection of glucose into starved silkworm larvae [81]. In contrast, CNS levels of bombyxin-II increased as the hemolymph titer fell in food-deprived B. mori larvae. Therefore, as hemolymph glucose levels rise in feeding insects, CNS insulin-like peptides may be released and act to stimulate trehalose utilization in tissues such as the midgut and muscles [81,109].

Hemolymph trehalose levels, which can fluctuate from 5 to $100 \mathrm{mM}$, may reflect the protein and carbohydrate needs of the insect [132]. Thompson and Redak [134] proposed that regulation of caterpillar physiological and behavioral responses to diet quality was associated with threshold levels of trehalose in the blood. This is supported by the observation that injection of trehalose, but not other sugars such as lactose, into the hemolymph of protein-conditioned caterpillars caused rejection of a high sucrose diet, which was selected by the controls [36]. Compelling evidence suggests that the correlation between hemolymph trehalose levels and feeding behavior may be related to the biogenic amine serotonin [23,24]. Starved H. zea larvae or ones fed on a carbohydrate-rich diet had higher levels of serotonin in the CNS than larvae fed on a balanced or protein-rich diet. Also, following transfer of larvae from the protein-rich to carbohydrate-rich diet, levels of CNS serotonin were closely correlated with carbohydrate intake [23]. Furthermore, interruption of serotonin biosynthesis following $p$ chlorophenylalanine treatment resulted in the consumption of double the amount of sucrose as the controls. Levels of CNS serotonin in caterpillars fed a sucrose diet containing tryptophan, the biosynthetic precursor to serotonin (5-hydroxytryptophan), were higher than in larvae reared on an optimal diet but not significantly different from those fed a sucrose diet alone [23]. Thus, hemolymph trehalose and serotonin levels in the CNS increase as larvae feed on the sucrose diet, and when trehalose levels reach a certain threshold, insects seek a 
different quality food source to balance their dietary needs (Fig. 2B) [23,134].

At present, it is not clear what mediates the change from a protein- to carbohydrate-diet, although this also may be related to hemolymph trehalose levels, since diet-switching behavior also occurs when levels fall below a $30 \mathrm{mM}$ threshold [132] (Fig. 2C). There are mechanisms to co-ordinate and target protein and carbohydrate nutrient intake levels. In locust, hemolymph levels of eight free amino acids (Ala, Met, Val, Phe, Leu, Ser, Lys, and Glu) have been connected with the cessation of feeding [1]. On protein-biased diets, one of these amino acids, lysine is specifically egested to allow locusts to feed sufficiently to meet dietary carbohydrate requirements [148].

Serotonin and octopamine may also interact to affect digestive processes in caterpillars. Serotonin stimulated gut contractions in larvae of the cabbage white butterfly, Pieris rapae and the fall army worm, S. frugiperda in vitro $[47,144]$, whereas serotonin-induced gut contractions were antagonized by octopamine [144].

\section{Role of gut-associated endocrine peptides}

Throughout the gut of insects, there are small endocrine cells interspersed between the columnar and goblet epithelial cells; these cells possess slender, apical extensions into the lumen of the midgut and their basal surfaces are in contact with the hemocoel. They are in a prime position to monitor both gut and hemolymph status, as well as to send paracrine or endocrine signals to regulate digestive processes. These cells contain a variety of neuropeptides, including allatostatins (ASTs), FLRFamides and tachykinins [94,96]. Although these neuropeptides were initially named because of their association with a specific physiological function/process, they are now known to be pleiotropic, with actions that may depend on species, ontological stage and ecological conditions [83,97]. Midgut cells of locusts fed a balanced P:C diet show elevated endopolyploidy, which may be related to the increased synthesis of these endocrine peptides, compared to insects restricted to extreme diets [158].

Allatotropin (AT) is a multifunctional peptide, with actions not only on the stimulation of juvenile hormone production in Lepidoptera, but also on muscle contraction of the midgut, as well as cardiac muscle $[30,63]$ and the ventral diaphragm [64]. AT treatment inhibits active ion transport across the epithelium in larval midgut of M. sexta in vitro [74]. Expression of AT has been demonstrated in the midgut but its precise cellular localization remains to be determined [75]. Release of AT from the midgut could, by way of ion transport, influence the transport and utilization of nutrients from the midgut at specific times, for example during periods of starvation associated with gut purge, ecdysis and pupation [74]. Its cardioacceleratory myotropic effect could similarly contribute to the distribution of nutrients and other neuropeptides in the hemolymph and gut (Fig. 2A). These pleiotropic actions of AT could be regulated by the different forms of AT arising from alternative splicing of the AT gene at different stages [30].

Crustacean Cardioactive peptide (CCAP) is a neuropeptide found in the gut endocrine cells that could also play a role in caterpillar nutrition. CCAP was first isolated from and shown to have myostimulatory activity on cardiac muscle in the shore crab, Carcinus maenas [127]. This peptide has subsequently been isolated from many lepidopteran species $[6,21,38,77]$. In the midgut of $P$. americana, CCAP is localized in the endocrine cells and the major nerve of the stomatogastric system, the ingluvial ganglion, which sends processes into the foregut and anterior hindgut [107]. CCAP may be involved in the response to dietary nutrients and may influence digestive processes since cellular CCAP levels rise in cockroach midgut following feeding on protein or starch diets relative to non-nutritive talc [108]. Incubation of cockroach midgut with CCAP increased activity of $\alpha$-amylase, which catalyzes the hydrolysis of starch from dietary glucose, and protease cellular activity and $\alpha$-amylase secretion, as well as stimulated contractions of the fore-, midand hindgut $[107,108]$.

CCAP has been found in larvae of M. sexta, the southern armyworm, S. eridania and the tomato moth, Lacanobia oleracea $[6,21,38]$ and, therefore, could be involved in the regulation of $\alpha$-amylase activity and secretion in feeding caterpillars (Fig. 2D). In addition, CCAP may also play a role in modulating hemolymph trehalose levels through the activation of glycogen phosphorylase during times of brief starvation (Fig. 2A) $[95,152]$, as CCAP stimulates the release of AKH from the corpora cardiaca $[34,140]$.

FLRFamides, belonging to the RF-amide superfamily, are found in many insect tissues and function as neurotransmitters, neuromodulators and hormones with tissue- and developmental-specific roles in different insects [96]. In the locust, Locusta migratoria, FLRFamides are found in the midgut, particularly in the ampullar region at the junction of the midgut, hindgut and Malpighian tubules $[44,88,157]$ and are involved in different aspects of nutrition. At the onset of feeding, FLRFamide-related peptides (FaRPs) are released into the hemolymph and, during each feeding bout, levels in the endocrine cells are replenished through synthesis and/or uptake [157]. In starved individuals, FaRP immunoreactivity increases in midgut endocrine cells compared to controls [45,157]. SchistoFLRF-amide also influences the activity of digestive enzymes; $\alpha$-amylase activity increased in both the lumen and tissue midguts extracts incubated with this peptide, as did $\alpha$-glucosidase activity in the lumen contents [46]. Similarly, FaRPs appear to modulate the release of invertase, which catalyzes the breakdown of sucrose to fructose and glucose, in midguts of the Pacific beetle cockroach, Diploptera punctata [39]. Furthermore, myosuppressins, a sub-group of FLRF-amides, regulate food movement into the midgut the site of digestion and nutrient absorption $[62,65]$ through inhibition of visceral muscle contractions in different parts of the gut [65]. FaRPs have been implicated in the maintenance of nutritional balance in locusts, with both quantities levels and distribution differing between individuals reared on balanced and unbalanced diets, as well as for those that were fed the same P:C ratio but at different concentrations $[45,157]$. Gut content of FLRF amide in locusts varies as a function of age, relative to both diet quality and concentration [157].

FLRFamides have been found in a number of lepidopteran larvae, including the wax moth, Galleria mellonella, H. zea, M. sexta, the gypsy moth, Lymantria dispar and B. mori [49,62,78,154]. These peptides could play several roles in the co-ordination and regulation of larval digestive processes (Fig. 2B). In endocrine 
midgut cells of $M$. sexta, there are three FaRPs, encoded by a single gene and the different peptides may be generated through tissue- and development-specific processing [62,78]. As seen in locusts, FaRP content in both midgut and hemolymph are affected by feeding state $[55,155]$. The content of gut FaRPs of M. sexta was higher in starved than in fed insects [155]. This is likely attributable to an increase in the number of endocrine cells in the gut expressing FaRPs rather than an increase in the actual amount within each cell [154]. A different pattern was seen in $\mathrm{H}$. zea larvae that had been starved for $48 \mathrm{~h}$, as the midgut levels of FaRPs dropped and hemolymph levels increased [55]. These differences may be a consequence of the length of the starvation period and/or are species-specific, but irrespective, they do not negate the idea that FaRPs are associated with the physiology of larval feeding.

As FLRFamides inhibit AKH synthesis and secretion in $L$. migratoria [141], one could postulate that while feeding, caterpillars have high levels of immediately available glucose; the release of FLRF amides could inhibit the release of AKH and, thus, ensure that glycogen phosphorylase is not activated (Fig. 2). Coincidentally, the release of the FLRFamides could lead to an increase in activity of digestive enzymes such as $\alpha$ amylase and facilitate the digestion and uptake of the ingested food. This idea is further supported by findings that at certain doses, FaRPs stimulate the release of $\alpha$-amylase in the gut lumen of Opisinia arenosella larvae, whereas at lower concentrations, there is an inhibitory effect [42]. The opposing sequence of events could pertain to starving individuals that are dependent on the breakdown of glycogen as a source of trehalose and have no immediate need for increased hydrolytic activity in the gut lumen. Although there have been several studies investigating the effect of FLRFamides on flight muscle in adult Lepidoptera [37,61], little is known about their effects on gut muscles of caterpillars, therefore, this physiological aspect also merits investigation.

\section{Future directions}

There is a growing body of evidence indicating that endocrine peptides, such as AST, AKH, CCAP and FLRFamides, and biogenic amines are part of complex regulatory loops involved in coordinating key aspects in insect digestive processes, including enzyme secretion, muscle contraction, ion transport and foraging behavior $[39,42,46,62,65,97]$. However, we still need a better understanding of the processes involved. An outline of potential interactions that merit clarification, based on information in this review, is presented in Fig. 2. The same neuropeptide may play very different roles in different species, so we realize that the proposed interactions drawn from an interspecific database may not all hold true for caterpillars. However, we believe that this model provides a good point of departure when designing experiments to study the roles of neuropeptides, for ultimately they will increase our basic understanding of caterpillar nutrition. These data also have relevance from a broader ecological perspective, as well as in pest management.

Atmospheric carbon dioxide levels are predicted to double by the end of the century [100]. The resulting climate changes will significantly affect plant carbon and nitrogen allocation and consequently levels of insect herbivory [76,138]. Thus, understanding the flexibility of the physiological/biochemical processes governing feeding behaviors of caterpillars could be useful in predicting the distribution and abundance of both insect and plant species.

From a practical perspective, given the economic importance of many lepidopteran species, we believe that a better appreciation of the roles of neuropeptides in different facets of caterpillar nutrition will provide potential alternatives for the control of pest species. Selecting plant cultivars with suboptimal P:C ratios might reduce damage and potentially lead to higher pest mortality, assuming that the caterpillars leave such plants in search of more suitable ones. A beneficial effect may also be realized if larvae remain on sub-optimal plants, resulting in a slower rate of growth, reduced fecundity and/or increased mortality from prolonged exposure to natural enemies [101,128]. However, there is substantial evidence to suggest that, in response to low protein quality, insect herbivores overcompensate by consuming more food, leading to higher levels of defoliation $[66,147]$. Another more promising avenue is the development of stable peptide analog mimetics and pesticides that interfere with specific physiological functions; a number of the peptides appear to be unique to arthropods and are, therefore, likely to have fewer undesirable ecological side effects.

The direct and indirect effects of other endocrine peptide effectors not discussed here will have to be integrated into the overall scheme presented in Fig. 2. Furthermore, the importance of the pathways may vary with other physiological and ecological parameters. For example, the activity of endocrine peptides is dose-dependent although at high concentrations, the effect may be abolished or truncated [22]. Such effects may be stage-specific, and the outcome of a feeding bout could differ markedly depending on abiotic conditions such as temperature [146]. In addition, several different neuropeptide families may induce the same response in vitro and, thus, one challenge will be to clarify how the "chemical language" (sensu [125]) actually functions in vivo [126].

\section{Acknowledgements}

We thank Paul Albert, Nadia Colasurdo, Emma Despland, Magali Merxk-Jacques and Mariana Sandoval, Steve Simpson and two anonymous reviewers for their insightful comments on this manuscript.

\section{R E F E R E N C E S}

[1] Abisgold JD, Simpson SJ. The physiology of compensation by locusts for changes in dietary protein. J Exp Biol 1987;129:329-46.

[2] Abisgold JD, Simpson SJ. The effect of dietary protein levels and haemolymph concentration on the sensitivity of the maxillary palp chemoreceptors of locusts. J Exp Biol 1988;135:215-29.

[3] Adamo SA. Feeding suppression in the tobacco hornworm, Manduca sexta: costs and benefits to the parasitic wasp Cotesia congregata. Can J Zool 1998;76:1634-40. 
[4] Ahmad I, Waldbauer GP, Friedman S. Maxillectomy does not disrupt self-selection by larvae of Manduca sexta (Lepidoptera: Sphingidae). Ann Entomol Soc Am 1993;86:459-63.

[5] Appelbaum SW, Schlesinger HM. Regulation of locust fatbody phosphorylase. Biochem J 1973;135:37-41.

[6] Audsley N, Weaver RJ. Identification of neuropeptides of larval Manduca sexta and Lacanobia oleracea using MALDITOF mass spectrometry and post-source decay. Peptides 2003;24:1465-74.

[7] Augner M. Low nutritive quality as a plant defenseeffects of herbivore-mediated interactions. Evol Ecol 1995;9:605-16.

[8] Awmack CS, Leather SR. Host plant quality and fecundity in herbivorous insects. Ann Rev Entomol 2002;47:817-44.

[9] Becker A, Schloder P, Steele JE, Wegener G. The regulation of trehalose metabolism in insects. Experientia 1996;52:433-9.

[10] Becker A, Wegener G. Hypertrehalosaemic neuropeptides decrease levels of the glycolytic signal fructose 2,6bisphosphate in the cockroach fat body. J Exp Biol 1998;201:1939-46.

[11] Becker A, Liewald JF, Stypa H, Wegener G. Antagonistic effects of hypertrehalosemic neuropeptide on the activities of 6-phosphofructo-1-kinase and fructose-1,6bisphosphatase in the cockroach fat body. Insect Biochem Mol Biol 2001;31:381-92.

[12] Behmer ST, Simpson SJ, Raubenheimer D. Herbivore foraging in chemical heterogeneous environments: nutrients and secondary metabolites. Ecology 2002;83:2489-501.

[13] Behmer ST, Cox E, Raubenheimer DJ, Simpson SJ. Food distance and its effects on nutrient balancing in a mobile insect herbivore. Anim Behav 2003;66:665-75.

[14] Bernays EA. Neural limitations in phytophagous insects: implications for diet breadth and evolution of host affiliation. Ann Rev Entomol 2001;46:703-27.

[15] Bernays EA, Singer MS, Rodrigues D. Foraging in nature: foraging efficiency and attentiveness in caterpillars with different diet breadths. Ecol Entomol 2004;29:389-97.

[16] Bernays EA, Chapman RF, Singer MS. Changes in taste receptor cell sensitivity in a polyphagous caterpillar reflect carbohydrate but not protein imbalance. J Comp Physiol 2004;190A:39-48.

[17] Brogiolo W, Stocker H, Ikeya T, Rintelen F, Fernandez R, Hafen E. An evolutionarily conserved function of the Drosophila insulin receptor and insulin-like peptides in growth control. Curr Biol 2001;11:213-22.

[18] Bruce TJA, Wadhams LJ, Woodcock CM. Insect host location: a volatile situation. Trends Plant Sci 2005;10:26974.

[19] Candy DJ, Becker A, Wegener G. Coordination and integration of metabolism in insect flight. Comp Biochem Physiol 1997;117B:497-512.

[20] Chapman RF. Chemosensory regulation of feeding. In: Chapman RF, de Boer G, editors. Regulatory mechanisms in insect feeding. New York: Chapman \& Hall; 1995. p. 101-36.

[21] Cheung CC, Loi PK, Sylwester AW, Lee TT, Tublitz NJ. Primary structure of a cardioactive neuropeptide from the tobacco hawkmoth Manduca sexta. FEBS Lett 1992;313:1658.

[22] Clark L, Zhang JR, Tobe SS, Lange AB. Proctolin: a possible releasing factor in the corpus cardiacum/corpus allatum of the locust. Peptides 2006;27:559-66.

[23] Cohen RW, Friedman S, Waldbauer GP. Physiological control of nutrient self-selection in Heliothis zea larvae: the role of serotonin. J Insect Physiol 1988;34:935-40.
[24] Cohen RW. Diet balancing in the cockroach Rhyparobia madera: does serotonin regulate this behavior? J Insect Behav 2001;14:99-111.

[25] Davenport AP, Evan PD. Changes in hemolymph octopamine levels associated with food deprivation in the locust, Schistocerca gregaria. Physiol Entomol 1984;9:269-74.

[26] Delisle J, Hardy M. Male larval nutrition influences the reproductive success of both sexes of the spruce budworm, Choristoneura fumiferana (Lepidoptera: Tortricidae). Funct Ecol 1997;11:451-63.

[27] Despland E, Noseworthy M. How well do specialist feeders regulate nutrient intake? Evidence from a gregarious treefeeding caterpillar. J Exp Biol 2006;209:1301-9.

[28] Ehrlich PR, Raven PH. Butterflies and plants: a study in coevolution. Evolution 1964;18:586-608.

[29] Eichenseer H, Mathews CM, Bi JL, Murphy B, Felton GW. Salivary glucose oxidase: multifunctional roles for Helicoverpa zea. Arch Insect Biochem Physiol 1999;42:99-109.

[30] Elekonich MM, Horodyski FM. Insect allatotropins belong to a family of structurally-related myoactive peptides present in several invertebrate phyla. Peptides 2003;24:1623-32.

[31] Farmer EE. Surface-to-air signals. Nature 2001;411:854-6.

[32] Felton GW. Nutritive quality of plant protein: sources of variation and insect herbivore responses. Arch Insect Biochem Physiol 1996;32:107-30.

[33] Fields PE, Woodring JP. Octopamine mobilization of lipids and carbohydrates in the house cricket, Acheta domesticus. J Insect Physiol 1991;37:193-9.

[34] Flanigan JE, Gäde G. On the release of the three locust (Locusta migratoria) adipokinetic hormones: effect of crustacean cardioactive peptide and inhibition by sugars. J Biosci 1999;54:110-8.

[35] Fraenkel GS. The raison d'être of secondary plants substances. Science 1959;219:1466-70.

[36] Friedman S, Waldbauer GP, Eertmoed JE, Naeem M, Ghent AW. Blood trehalose levels have a role in the control of dietary self-selection by Heliothis zea larvae. J Insect Phys 1991;37:919-28.

[37] Fujisawa Y, Shimoda M, Kiguchi K, Ichikawa T, Fujita N. The inhibitory effect of a neuropeptide, Manduca FLRFamide, on the midgut activity of the sphingid moth, Agrius convolvuli. Zool Sci 1993;10:773-7.

[38] Furuya K, Liao S, Reynolds SE, Ota RB, Hackett M, Schooley DA. Isolation and identification of a cardioactive peptide from Tenebrio molitor and Spodoptera eridania. Biol Chem Hoppe-Seyler 1993;374:1065-74.

[39] Fusé M, Zhang JR, Partridge E, Nachman RJ, Orchard I, Bendena WG, et al. Effects of an allatostatin and a myosuppressin on midgut carbohydrate enzyme. Peptides 1999;20:747-56.

[40] Gies A, Fromm T, Zeigler R. Energy metabolism in starving larvae of Manduca sexta. Comp Biochem Physiol 1988;91A:549-55.

[41] Hägele BF, Rowell-Rahier M. Dietary mixing in three generalist herbivores: nutrient complementation or toxin dilution. Oecologia 1999;119:521-33.

[42] Harshini S, Nachman RJ, Sreekumar S. In vitro release of digestive enzymes by FMRFamide related neuropeptides and analogues in the lepidopteran insect Opisina arenosella (Walk). Peptides 2002;23:1759-63.

[43] Hilker M, Meiners T. Induction of plant responses to oviposition and feeding by herbivorous arthropods: a comparison. Entomol Exp Applicata 2002;104:181-92.

[44] Hill SR, Orchard I. FMRFamide-related proteins in the gut of Locusta migratoria L: a comprehensive map and developmental profile. Peptides 2003;24:1511-24. 
[45] Hill SR, Orchard I. The influence of diet and feeding state on FMRF amide-related peptides in the gut of Locusta migratoria L.. Peptides 2004;25:105-14.

[46] Hill SR, Orchard I. In vitro analysis of the digestive enzymes amylase and $\alpha$-glucosidase in the midguts of Locusta migratoria L. in response to the myosuppressin, SchistoFLRFamide. J Insect Physiol 2005;51:1-9.

[47] Howarth CJ, Prince RI, Dyker H, Lösel PM, Seinsche A, Osborne RH. Pharmacological characterization of 5hydroxytrypamine-induced contractile effects in the isolated gut of the lepidopteran caterpillar Spodoptera frugiperda. J Insect Physiol 2002;48:43-52.

[48] Hoy CW, Head GP, Hall FR. Spatial heterogeneity and insect adaptation to toxins. Ann Rev Entomol 1998;43:571-94.

[49] Huang Y, Brown MR, Lee TD, Crim JW. RF-amide peptides isolated from the midgut of the corn earworm, Helicoverpa zea, resemble pancreatic polypeptide. Insect Biochem Mol Biol 1998;28:345-56.

[50] Hunter MD, McNeil JN. Host-plant quality influences diapause and voltinism in a polyphagous insect herbivore. Ecology 1997;78:977-86. pp.2267-2268.

[51] Ikeya T, Galic M, Belawat P, Nairz K, Hafen E. Nutrientdependent expression of insulin-like peptides from neuroendocrine cells in the CNS contributes to growth regulation in Drosophila. Curr Biol 2002;12:1293-300.

[52] Isabel G, Martin JR, Chimdami S, Veenstra JA, Rosay P. AKH-producing neuroendocrine cell ablation decreases trehalose and induces behaviour changes in Drosophila. Am J Physiol-Regul Integr Comp Physiol 2005;288:531-8.

[53] Ismail SMM, Matsumura F. Studies on the biochemical mechanisms of anorexia caused by formamidine pesticides in the tobacco hornworm Manduca sexta. Insect Biochem Mol Biol 1992;22:713-20.

[54] Jahagirdar AP, Downer RGH, Viswanatha T. Influence of octopamine on trehalase activity in muscle and hemolymph of the American cockroach. P. americana L.. Biochem Biophys Acta 1984;801:177-83.

[55] Jenkins AC, Brown MR, Crim JW. FMRF-amide immunoreactivity and the midgut of the corn earworm (Heliothis zea). J Exp Zool 1989;252:71-8.

[56] Karban R, Baldwin IT. Induced Responses to Herbivory. Chicago: University of Chicago Press; 1997.

[57] Karowe DN, Martin MM. The effects of quantity and quality of diet nitrogen on the growth, efficiency of food utilization, nitrogen budget, and metabolic rate of fifthinstar Spodoptera eridania larvae (Lepidoptera: Noctuidae). J Insect Physiol 1989;35:699-708.

[58] Kawakami A, Iwami M, Nagasawa H, Suzuki A, Ishizaki H. Structure and organization of four clustered genes that encode Bombyxin, an insulin-related brain secretory peptide of the silkmoth Bombyx mori. Proc Natl Acad Sci 1989;86:6843-7.

[59] Kessler A, Baldwin IT. Defensive function of herbivoreinduced plant volatile emissions in nature. Science 2001;291:2141-4.

[60] Kessler A, Baldwin IT. Plant responses to insect herbivory: the emerging molecular analysis. Ann Rev Plant Biol 2002;53:299-328.

[61] Kingan TG, Shabanowitz J, Hunt DF, Witten JL. Characterization of two myotropic neuropeptides in the FMRFamide family from segmental ganglia of the moth Manduca sexta: candidate neurohormones and neuromodulators. J Exp Biol 1996;199:1095-104.

[62] Kingan TG, Zitnan D, Jaffe H, Beckage NE. Identification of neuropeptides in the midgut of parasitized insects: FLRFamides as candidate peptides. Mol Cell Endocrinol 1997;133:19-32.
[63] Koladich PM, Cusson M, Bendena WG, Tobe SS, McNeil JN. Cardioacceleratory effects on Manduca sexta allatotropin in the true armyworm moth, Pseudaletia unipuncta. Peptides 2002;23:645-51.

[64] Koladich PM, Tobe SS, McNeil JN. Enhanced haemolymph circulation by insect ventral nerve cord: hormonal control by Pseudaletia unipuncta allatotropin and serotonin. J Exp Biol 2002;205:3123-31.

[65] Lange AB, Orchard I. The effects of SchistoFLRFamide on contractions of the locust midgut. Peptides 1998;19:459-67.

[66] Lavoie B, Oberhauser KS. Compensatory feeding in Danaus plexippus (Lepidoptera: Nymphalidae) in response to variation in host plant quality. Environ Entomol 2004;33:1062-9.

[67] Lee G, Park JH. Hemolymph sugar homeostasis and starvation-induced hyperactivity affected by genetic manipulations of the adipokinetic hormone-encoding gene in Drosophila melanogaster. Genetics 2004;167:311-23.

[68] Lee KP, Behmer ST, Simpson SJ, Raubenheimer D. A geometric analysis of nutrient regulation in the generalist caterpillar Spodoptera littoralis (Boisduval). J Insect Physiol 2002;48:655-65.

[69] Lee KP, Raubenheimer D, Behmer ST, Simpson SJ. A correlation between macronutrient balancing and insect host-plant range: evidence from the specialist caterpillar Spodoptera exempta (Walker). J Insect Physiol 2003;49:116171.

[70] Lee KP, Raubenheimer D, Simpson SJ. The effects of nutritional imbalance on compensatory feeding for cellulose-mediated dietary dilution in a generalist caterpillar. Physiol Entomol 2004;29:108-17.

[71] Lee KP, Simpson SJ, Raubenheimer D. A comparison of nutrient regulation between solitarious and gregarious phases of the specialist caterpillar, Spodoptera exempta (Walker). J Insect Physiol 2004;50:1171-80.

[72] Lee KP, Cory JS, Wilson K, Raubenheimer D, Simpson SJ. Flexible diet choice offsets protein costs of pathogen resistance in a caterpillar. Proc R Soc B Biol Sci 2006;273:823-9.

[73] Lee KP, Behmer ST, Simpson SJ. Nutrient regulation in relation to diet breadth: a comparison of Heliothis sister species and a hybrid. J Exp Biol 2006;209:2076-84.

[74] Lee KY, Chamberlin ME, Horodyski FM. Biological activity of Manduca sexta allatotropin-like peptides, predicted products of tissue-specific and developmentally regulated alternatively spliced mRNAs. Peptides 2002;23:1933-41.

[75] Lee KY, Horodyski FM. Restriction of nutrient intake results in the increase of a specific Manduca sexta allatotropin (Manse-AT) mRNA in the larval nerve cord. Peptides 2002;23:653-61.

[76] Lincoln DE, Fajer ED, Johnson RH. Plant-insect herbivore interactions in elevated $\mathrm{CO}_{2}$ environments. Trends Evol Ecol 1993;8:64-8.

[77] Loi PK, Emmal SA, Park Y, Tublitz NJ. Identification, sequence and expression of a crustacean cardioactive peptide (CCAP) gene in the moth Manduca sexta. J Exp Biol 2001;204:2803-16.

[78] Lu D, Lee KY, Horodyski FM, Witten JL. Molecular characterization and cell-specific expression of a Manduca sexta FLRFamide gene. J Comp Neurol 2002;446:377-96.

[79] Lucas PW, Turner IM, Dominy NJ, Yamashita N. Mechanical defences to herbivory. Ann Bot 2000;86:913-20.

[80] Marshall LD, McNeil JN. Spermatophore mass as an estimate of male nutrient investment: a closer look in Pseudaletia unipuncta (Haworth) (Lepidoptera: Noctuidae). Funct Ecol 1989;3:605-12.

[81] Masumura M, Satake S, Saegusa H, Mizoguchi A. Glucose stimulates the release of Bombyxin, an insulin-related 
peptide of the silkworm Bombyx mori. Gen Comp Endocrinol 2000;118:393-9.

[82] Mattson Jr WJ. Herbivory in relation to plant nitrogen content. Ann Rev Ecol Syst 1980;11:119-61.

[83] McNeil JN, Tobe SS. Flights of fancy: possible roles of allatostatin and allatotropin in migration and reproductive success of Pseudaletia unipuncta. Peptides 2001;22:271-7.

[84] Merkx-Jacques M, Bede JC. Influence of diet on larval Spodoptera exigua glucose oxidase activity. J Insect Sci 2005;5:48.

[85] Meyer-Fernandes JR, Gondim KC, Wells MA. Developmental changes in the response of larval Manduca sexta fat body glycogen phosphorylase to starvation, stress and octopamine. Insect Biochem Mol Biol 2000;20:415-22.

[86] Meyer-Fernandes JR, Clark CP, Gondim KC, Wells MA. Fat body fructose-2,6-bisphosphate content and phosphorylase activity correlate with changes in hemolymph glucose concentration during fasting and refeeding in larval Manduca sexta. Insect Biochem Mol Biol 2001;31:165-70.

[87] Miles CI, Booker R. Octopamine mimics the effects of parasitism on the foregut of the tobacco hornworm Manduca Sexta. J Exp Biol 2000;203:1689-700.

[88] Montuenga LM, Prado MA, Springall DR, Polak JM, Sesma $P$. Endothelin-like immunoreactivity in midgut endocrine cells of the desert locust, Locusta migratoria. Gen Comp Endocrinol 1994;93:9-20.

[89] Moreau G, Quiring DT, Eveleigh ES, Bauce E. Advantages of a mixed diet: feeding on several foliar age classes increases the performance of a specialist herbivore. Oecologia 2003;135:391-9.

[90] Müller C, Riederer M. Plant surface properties in chemical ecology. J Chem Ecol 2005;31:2621-51.

[91] Murphy TA, Wyatt GR. Enzymes of glycogen and trehalose synthesis in silk moth fat body. J Biol Chem 1965;240:1500-8.

[92] Musser RO, Hum-Musser SM, Eichenseer H, Peiffer M, Ervin G, Murphy JB, et al. Herbivory: caterpillar saliva beats plant defenses. Nature 2002;416:599-600.

[93] Musser RO, Cipollini DF, Hum-Musser SM, Williams SA, Brown JK, Felton GW. Evidence that caterpillar salivary enzyme glucose oxidase provides herbivore offense in solanaceous plants. Arch Insect Biochem Physiol 2005;58:128-37.

[94] Nässel DR. Neuropeptides in the nervous system of Drosophila and other insects: multiple roles as neuromodulators and neurohormones. Prog Neurobiol 2002;68:1-84.

[95] Oda Y, Uejuma M, Iwami M, Sakurai S. Involvement of adipokinetic hormone in the homeostatic control of hemolymph trehalose concentrations in the larvae of Bombyx mori. Arch Insect Biochem Physiol 2000;45:156-65.

[96] Orchard I, Lange AB, Bendena WG. FMRFamide-related peptides: a multifunctional family of structurally related neuropeptides in insects. Adv Insect Physiol 2001;28:267-329.

[97] Orchard I. Aminergic and peptidergic control of feedingrelated activities in the blood-sucking bug, Rhodnius prolixus. J Exp Zool A Comp Exp Biol 2006;305A:166.

[98] Passier PC, Vullings HG, Diederen JH, Van der Horst DJ. Modulatory effects of biogenic amines on adipokinetic hormone secretion from locust corpora cardiaca in vitro. Gen Comp Endocrinol 1995;97:231-8.

[99] Passier PC, Vullings HG, Diederen JH, Van der Horst DJ. Trehalose inhibits the release of adipokinetic hormones from the corpus cardiacum in the African migratory locust, Locusta migratoria, at the level of the adipokinetic cells. J Endocrinol 1997;153:299-305.
[100] Prentice I, Farquhar G, Fasham M, Goulden M, Heinmann $\mathrm{M}$, et al. The carbon cycle and atmospheric carbon dioxide. In: Houghton JT, Ding Y, Griggs DJ, Noguer M, van der Linden PJ, Dai X, Maskell K, Johnson CA, editors. Climate change 2001: the scientific basis. Cambridge: Cambridge University Press; 2001. p. 183-238.

[101] Price PW, Bouton CE, Gross P, McPheron BA, Thompson JN, Weis AE. Interactions among three trophic levels: influence of plants on interactions between insect herbivores and natural enemies. Ann Rev Ecol Syst 1980;11:41-65.

[102] Raubenheimer D, Simpson SJ. Integrative models of nutrient balancing: application to insects and vertebrates. Nutr Res Rev 1997;10:151-79.

[103] Raubenheimer D, Simpson SJ. Nutrient balancing in grasshoppers: behaviour and physiological correlates of diet breadth. J Exp Biol 2003;206:1669-81.

[104] Roberts MR, Paul ND. Seduced by the dark side: integrating molecular and ecological perspectives on the influence of light on plant defence against pests and pathogens. New Phytol 2006;170:677-99.

[105] Roeder T. Octopamine in invertebrates. Prog Neurobiol 1999;59:533-61.

[106] Roslin T, Gripenberg S, Salminen JP, Karonen M, O'Hara $\mathrm{RB}$, Pihlaja K, et al. Seeing the trees for the leaves-oaks as mosaics for a host-specific moth. Oikos 2006;113:106-20.

[107] Sakai T, Satake H, Minakata H, Takeda M. Characterization of crustacean cardioactive peptide as a novel insect midgut factor: isolation, localization, and stimulation of $\alpha$-amylase activity and gut contraction. Endocrinology 2004;145:5671-8.

[108] Sakai T, Satake H, Takeda M. Nutrient-induced $\alpha$-amylase and protease activity is regulated by crustacean cardioactive peptide (CCAP) in the cockroach midgut. Peptides 2006;27:2157-64.

[109] Satake S, Masumura M, Ishizaki H, Nagata K, Kataoka H, Suzuki A, et al. Bombyxin, an insulin-related peptide in insects, reduces the major storage carbohydrates in the silkworm Bombyx mori. Comp Biochem Physiol 1997;118B:349-57.

[110] Satake S, Kawabe Y, Mizoguchi A. Carbohydrate metabolism during starvation in the silkworm Bombyx mori. Arch Insect Biochem Physiol 2000;44:90-8.

[111] Scriber JM, Slansky Jr F. The nutritional ecology of immature insects. Ann Rev Entomol 1981;26:183-211.

[112] Showler AT, Moran PJ. Effects of drought stressed cotton, Gossypium hirsutum L., on beet armyworm, Spodoptera exigua (Hubner), oviposition, and larval feeding preferences and growth. J Chem Ecol 2003;29: 1997-2011.

[113] Siegert KH. Carbohydrate metabolism in starved fifth instar larvae of Manduca sexta. Arch Insect Biochem Physiol 1986;4:151-60.

[114] Siegert KH, Zeigler R. A hormone from the corpora cardiaca controls fat body glycogen phosphorylase during starvation in tobacco hornworm larvae. Nature 1983;301:526-7.

[115] Siegert KH, Mordue W. Regulation of fat body glycogen phosphorylase activity during refeeding in Manduca sexta larvae. Arch Insect Biochem Physiol 1992;19:225-35.

[116] Simmonds MSJ, Simpson SJ, Blaney WM. Dietary selection behaviour in Spodoptera littoralis: the effects of conditioning diet and conditioning period on neural responsiveness and selection behaviour. J Exp Biol 1992;162:73-90.

[117] Simpson SJ, Simpson CL. The mechanisms of nutritional compensation by phytophagous insects. In: Bernays EA, editor. Insect-plant interactions, vol. II. Boca Raton: CRC Press; 1990. p. 111-60. 
[118] Simpson SJ, White PR. Associative learning and locust feeding: evidence for a "learned hunger" for protein. Anim Behav 1990;40:506-13.

[119] Simpson SJ, Raubenheimer D. The central role of the haemolymph in the regulation of nutrient intake in insects. Physiol Entomol 1993;18:395-403.

[120] Simpson SJ, Raubenheimer D. Feeding behavior, sensory physiology and nutrient feedback: a unifying model. Entomol Exp Appl 1996;80:55-64.

[121] Simpson SJ, James S, Simmonds MSJ, Blaney WM. Variation in chemosensitivity and the control of dietary selection behaviour in the locust. Appetite 1991;17:141-54.

[122] Simpson SJ, Raubenheimer D, Behmer ST, Whitworth A, Wright GA. A comparison of nutritional regulation in solitarious- and gregarious-phase nymphs of the desert locust Schistocerca gregaria. J Exp Biol 2002;205:121-9.

[123] Simpson SJ, Sibly RM, Lee KP, Behmer ST, Raubenheimer D. Optimal foraging when regulating intake of multiple nutrients. Anim Behav 2004;68:1299-311.

[124] Singer MS, Bernays EA, Carrière Y. The interplay between nutrient balancing and toxin dilution in foraging by a generalist insect herbivore. Anim Behav 2002;64:629-43.

[125] Skaer NJV, Nässel DR, Maddrell SHP, Tublitz NJ. Neurochemical fine tuning of a peripheral tissue: peptidergic and aminergic regulation of fluid secretion by Malpighian tubules in the tobacco hawkmoth, Manduca sexta. J Exp Biol 2002;205:1869-80.

[126] Stadler E. Plant cues important for egg deposition by herbivorous insects. In: Hilker $\mathrm{M}$, Meiners $\mathrm{T}$, editors. Chemoecology of insect eggs and egg deposition. Oxford: Blackwell Publishing; 2002. p. 171-204.

[127] Stangier J, Hilbich C, Beyreuther K, Keller R. Unusual cardioactive peptide (CCAP) from pericardial organs of the shore crab, Carcinus maenas. Proc Natl Acad Sci USA 1987;84:575-9.

[128] Stiling P, Moon DC. Quality or quantity: the direct and indirect effects of host plants on herbivores and their natural enemies. Oecologia 2005;142:413-20.

[129] Stockhoff BA. Ontogenic change in dietary selection for protein and lipid by gypsy moth larvae. J Insect Physiol 1993;39:677-86.

[130] Telang A, Booton V, Chapman RF, Wheeler DE. How female caterpillars accumulate their nutrient reserves. J Insect Physiol 2001;47:1055-64.

[131] Telang A, Buck NA, Chapman RF, Wheeler DE. Sexual differences in postingestive processing of dietary protein and carbohydrate in caterpillars of two species. Physiol Biochem Zool 2003;76:247-55.

[132] Thompson SN. Trehalose-the insect "blood" sugar. Adv Insect Physiol 2003;31:205-85.

[133] Thompson SN, Lee RWK. NMR studies on gluconeogenesis and metabolism of [ ${ }^{1}$ C] 2 -pyruvate in Manduca sexta. Insect Biochem 1988;18:21-7.

[134] Thompson SN, Redak RA. Interactions of dietary protein and carbohydrate determine blood sugar level and regulate nutrient selection in the insect Manduca sexta L.. Biochim Biophys Acta 2000;1523:91-102.

[135] Thompson SN, Redak RA, Borchard DB. The The glucogenic response of a parasitized insect Manduca sexta L. is partially mediated by differential nutrient intake. Biochim Biophys Acta 2002;1571:138-50.

[136] Thompson SN, Borchardt DB, Wang LW. Dietary nutrient levels regulate protein and carbohydrate intake, gluconeogenic/glycolytic flux and blood trehalose level in the insect Manduca sexta L.. J Comp Physiol 2003;173B:14963.

[137] Thompson SN, Redak RA. Feeding behaviour and nutrient selection in an insect Manduca sexta L., and alterations induced by parasitism. J Comp Physiol A Neuroethol Sens Neural Behav Physiol 2005;191:909-23.

[138] Throop HL, Holland EA, Parton WJ, Ojima DS, Keough CA. Effects of nitrogen deposition and insect herbivory on patterns of ecosystem-level carbon and nitrogen dynamics: results from the CENTURY model. Global Change Biol 2004;10:1092-105.

[139] Van Den Boom CEM, Van Beek TA, Posthumas MA, De Groot A, Dicke M. Qualitative and quantitative variation among volatile profiles induced by Tetranychus urticae feeding on plants from various families. J Chem Ecol 2004;30:69-89.

[140] Veelaert D, Passier P, Devreese B, Van den Broeck J, Beeumen VJ, Vullings HGB, et al. Isolation and characterization of an adipokinetic hormone releaseinducing factor in locusts: the crustacean cardioactive peptide. Endocrinology 1997;138:138-42.

[141] Vullings HGB, Ten Voorde SE, Passier PC, Diederen JHB, Van den Horst DJ, Nässel DR. A possible role of SchistoFLRFamide in inhibition of adipokinetic hormone release from locust corpora cardiaca. J Neurocytol 1998;27:901-13.

[142] Waldbauer GP, Cohen RW, Friedman S. Self-selection of an optimal nutrient mix from defined diets by larvae of the corn earworm, Heliothis zea (Boddie). Physiol Zool 1984;57:590-7.

[143] Waldbauer GP, Friedman S. Self-selection of optimal diets by insects. Ann Rev Entomol 1991;36:43-63.

[144] Walker LE, Bloomquist JR. Pharmacology of contractile responses in the alimentary system of caterpillars: implications for insecticide development and mode of action. Ann Entomol Soc Am 1999;92:902-8.

[145] Wittstock U, Gershenzon J. Constitutive plant toxins and their role in defense against herbivores and pathogens. Curr Opin Plant Biol 2002;5:300-7.

[146] Wolesensky W, Joern A, Logan JD. A model of digestion modulation in grasshoppers. Ecol Model 2005;188:358-73.

[147] Woods HA. Patterns and mechanisms of growth of fifthinstar Manduca sexta caterpillars following exposure to low- or high-protein food during early instars. Physiol Biochem Zool 1999;72:445-54.

[148] Zannotto FP, Raubenheimer D, Simpson SJ. Haemolymph amino acid and sugar levels in locusts fed nutritionally unbalanced diets. J Comp Physiol B 1996;166:223-9.

[149] Zanotto FP, Goeveia SM, Simpson SJ, Raubenheimer D, Calder PC. Nutritional homeostasis in locusts: is there a mechanism for increased energy expenditure during carbohydrate overfeeding? J Exp Biol 1997;200:2437-48.

[150] Ziegler R. Developmental changes in the response of the fat body of Manduca sexta to injections of corpora cardiaca extracts. Gen Comp Endocrinol 1984;54:51-8.

[151] Ziegler R. Biological effects of synthetic AKH in Manduca sexta and estimates of the amount of AKH in the corpora cardiaca. Arch Insect Biochem Physiol 1990;15:111-6.

[152] Zieger R, Eckart K, Law JH. Adipokinetic hormone controls lipid metabolism in adults and carbohydrate metabolism in larvae of Manduca sexta. Peptides 1990;11:1037-40.

[153] Ziegler R, Willingham LA, Sanders SJ, Tamen-Smith L, Tsuchida K. Apolipophorin-III and adipokinetic hormone in lipid metabolism of larval Manduca sexta. Insect Biochem Mol Biol 1995;25:101-8.

[154] Žitňan D, Šauman I, Sehnal F. Peptidergic innervation and endocrine cells of the insect midgut. Arch Insect Biochem Physiol 1992;22:113-32.

[155] Žitňan D, Kingan KG, Beckage NE. Parasitism-induced accumulation of FMRFamide-like peptides in the gut innervation and endocrine cells of Manduca sexta. Insect Biochem Mol Biol 1995;25:669-78. 
[156] Zong N, Wang CZ. Induction of nicotine in tobacco by herbivory and its relation to glucose oxidase activity in the labial gland of three noctuid caterpillars. Chin Sci Bull 2004;49:1596-601.

[157] Zudaire E, Simpson SJ, Montuenga LM. Effects of food nutrient content, insect age and stage in the feeding cycle on the FMRFamide immunoreactivity of diffuse endocrine cells in the locust gut. J Exp Biol 1998;201:2971-9.

[158] Zudaire E, Simpson SJ, Illa I, Montuenga LM. Dietary influences over proliferating cell nuclear antigen expression in the locust midgut. J Exp Biol 2004;207: 2255-65. 